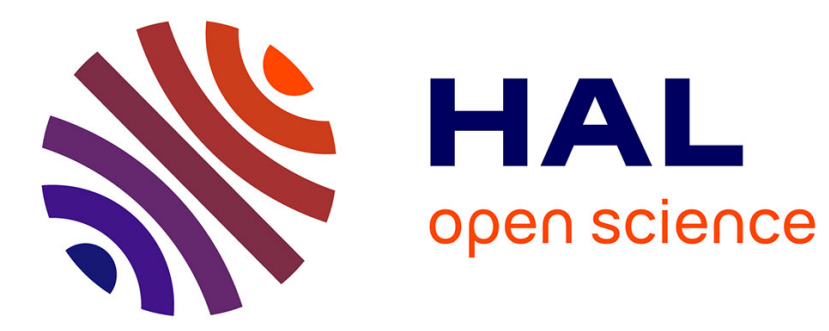

\title{
End of 9-endings, price recall, and price perceptions
} Avichai Snir, Daniel Levy, Haipeng Allan Chen

\section{To cite this version:}

Avichai Snir, Daniel Levy, Haipeng Allan Chen. End of 9-endings, price recall, and price perceptions.

Economics Letters, 2017, 155, pp.157-163. 10.1016/j.econlet.2017.04.001 . hal-02387743

\section{HAL Id: hal-02387743 \\ https://hal.science/hal-02387743}

Submitted on 30 Nov 2019

HAL is a multi-disciplinary open access archive for the deposit and dissemination of scientific research documents, whether they are published or not. The documents may come from teaching and research institutions in France or abroad, or from public or private research centers.
L'archive ouverte pluridisciplinaire HAL, est destinée au dépôt et à la diffusion de documents scientifiques de niveau recherche, publiés ou non, émanant des établissements d'enseignement et de recherche français ou étrangers, des laboratoires publics ou privés. 


\title{
End of 9-Endings, Price Recall, and Price Perceptions
}

\author{
Avichai Snir ${ }^{\mathrm{a}}$, Daniel Levy ${ }^{\mathrm{b}, \mathrm{c}, \mathrm{d} *}$, Haipeng (Allan) Chen $^{\mathrm{e}}$ \\ a Department of Banking \& Finance, Netanya Academic College, Netanya 42365, ISRAEL \\ ${ }^{\mathrm{b}}$ Department of Economics, Bar-Ilan University, Ramat-Gan 52900, ISRAEL \\ ${ }^{\mathrm{c}}$ Department of Economics, Emory University, Atlanta, GA 30322, USA \\ ${ }^{\mathrm{d}}$ The Rimini Centre for Economic Analysis, Via Patara, 3 - 47921, Rimini (RN) ITALY \\ ${ }^{\mathrm{e}}$ Mays Business School, Texas A\&M University, College Station, TX 77843, USA
}

Last revision: April 2, 2017

\begin{abstract}
Prices that end with 9, also known as psychological price points, are common, comprising about $70 \%$ of the retail prices. They are also more rigid than other prices. We take advantage of a natural experiment to document an emergence of a new price ending that has the same effects as 9-endings. In January 2014, the Israeli government passed a new regulation prohibiting the use of non 0-ending prices, bringing an end to 9ending prices. We find that seven months after 9-ending prices have disappeared, 90ending prices acquired the same status as 9-ending prices had before the new regulation was adopted. Thus, 90-ending prices became the new psychological price points, partially eliminating the regulation's intended effect.
\end{abstract}

\section{JEL Classification:}

E31, L16, K20, D40, D83, L81, M21, M31

\section{Keywords:}

9-ending prices; psychological price points; price recall; price perception; sticky prices; rigid prices; price rigidity; price flexibility; price stickiness; level effect; left-digit effect; image effect; right-digit effect; integer constraint; price control; price regulation

\footnotetext{
We thank two anonymous reviewers for thoughtful comments, which helped us improve the data analyses and better position the paper in the context of the existing literature, and Doron Sayag for his help with the data. All authors contributed equally: we rotate co-authorship. Any remaining errors are ours.

* Corresponding author. Tel: +972 35318331

E-mail address: Daniel.Levy@biu.ac.il (D. Levy)
} 


\section{Introduction}

9-ending prices are common, comprising about $70 \%$ of the retail prices. They are also more rigid than other prices (Kashyap 1995, Blinder et al 1998, Levy et al 2011, Knotek 2010, Anderson et al 2015, McShane et al 2015). Their ubiquity and rigidity are explained by 9endings' positive effect on revenues (Anderson and Simester 2003), which is attributed to 9endings being psychological price points, implying that they affect shoppers’ price perceptions. ${ }^{1}$ Two leading explanations for this effect are level-effect and image-effect. ${ }^{2}$

According to the level-effect, consumers have bounded rationality and, therefore, they round prices down or process price information L-to-R, and sometimes ignore the rightmost digit (Schindler and Kirby 1997, Stiving and Winer 1997, Thomas and Morwitz 2005). According to the image-effect, 9-endings signal low prices and so, consumers are drawn to goods with 9-ending prices even when other goods have lower prices (Anderson and Simester 2003, Stiving 2000).

In January 2014, the Israeli government adopted a new regulation prohibiting the use of non 0-ending prices. We take advantage of this natural experiment to study the effects of eliminating 9-ending prices on consumers' price recall and price perceptions. We combine instore posted price data from supermarkets with three consumer survey data, collected before, immediately after, and 7-months after the regulatory change. In the surveys, shoppers were asked to recall the prices they have paid, and indicate any price change they have noticed.

We find that before the regulation, (1) the most common price-ending was 9, and (2) shoppers made larger errors in recalling 9-ending prices in comparison to other prices. In addition, Levy et al. (2016) report that (3) the likelihood of noticing a price change was smaller for 9-ending prices than for other prices. Immediately after the regulation, shoppers' price recall accuracy improved relative to the period prior to the change. Further, although 90 became the most common price ending immediately after the change, they had no negative effect on price recall accuracy.

One year after the regulation, however, we find that (1) 90 is the most common price ending, (2) shoppers make larger errors in recalling 90-ending prices than other prices, and (3) the likelihood of noticing a price change is smaller for 90-ending prices in comparison to other prices. Thus, after the regulation, 90-ending prices seem to have influence similar to the influence 9-ending prices had before the change; 90-ending prices are the new psychological price points. We further find that the effect of 90-endings is consistent with the image-effect.

Ater and Gerlitz (2016) also use this particular episode of regulatory change in Israel.

\footnotetext{
${ }^{1}$ According to Landsburg (2012), dollar-store owners in the late $19^{\text {th }}$ century began using $99 \$$ pricing to make it harder for cashiers to steal, and thus inadvertently discovered the benefits of 9-ending prices as psychological price points.

${ }^{2}$ In the literature, level-effect and image-effect are sometimes described as left-digit effect and right-digit effect, respectively.
} 
They, however, study a theory of price rigidity, while we study shoppers' price recall and price perceptions. ${ }^{3,4}$ A second related study is Aalto-Setala (2005), who studies another natural experiment, the Euro changeover (Ehrmann, 2012). He looks at the dynamic adjustment of retail price endings in Finland during and following the 2002 Euro transition. There are important differences between the Israeli and Finish episodes, since the Euro changeover involved a currency conversion. Despite this, we find interesting similarities between the two episodes, as discussed below.

In section 2, we discuss the regulatory change. In section 3, we describe the data. In section 4, we discuss the estimation results. We conclude in section 5.

\section{Abolition of non 0-ending prices: a natural experiment}

The 0.01 New Israeli Shekel (1-agora) and the NIS 0.05 (5-agora) coins were eliminated in 1991 and 2008, respectively. They are not in use since, but until January 2014, the retailers were free to set any price ending. ${ }^{5}$ In credit-card transactions, shoppers paid the exact amount. In cash transactions, however, the total bill was rounded to the nearest 10-agora. For example, if the total bill was between NIS 7.45 and NIS 7.54, the actual amount paid was NIS 7.50.

The Israeli shoppers, however, felt that they were losing in cash transactions because the asymmetric rounding was tilted towards the retailers. More importantly, the public demanded to put an end to 9-ending prices because they perceived them as “unfair” and "manipulative.” In response to these public demands, the Minister of Economic Affairs announced in October 2013 that beginning January 1, 2014, all retail prices must end with $0 .^{6}$

Figure 1 illustrates the dynamic effect of the regulation by showing the distribution of

\footnotetext{
${ }^{3}$ Ater and Gerlitz (2016) test Blinder et al.’s $(1991,1998)$ theory, which argues that 9-endings form barriers to price changes, and therefore 9-ending prices will be more rigid than other prices. They compare the probability of prices to adjust before and after the regulation banning 9-endngs. Before the regulation, they find that 0 -ending prices were more likely to change, in comparison to non 0-ending prices. After the regulation, these differences disappeared. These findings, they conclude, support the price point theory.

${ }^{4}$ In addition, they use different data and different methodology. They use two large datasets: (1) Israeli Consumer Council's bimonthly price data, and (2) internet price data collected from supermarket websites. We use two small datasets: (1) handcollected, in-store, posted price data, and (2) three survey datasets which we collected by surveying supermarket shoppers, where they were asked to recall the prices they paid and indicate whether they noticed any price change (upward, downward, or no-change).

${ }^{5}$ The coins were eliminated because of their increased cost of production. For example, by 2008 the cost of minting a 5-agora coin was 16-agorot. In addition, the public was reluctant to accept them as a change, and vending machines, parking meters, and other coin-operated devices stopped accepting them. As of January 2014, only 0-edning prices (i.e., prices that end with $.10, .20, \ldots, .90)$ are allowed. See: www.boi.org.il/en/NewsAndPublications/PressReleases/Pages/070716e.aspx, and www.boi.org.il/press/eng/100815/100815d.htm (both accessed February 19, 2017).

${ }^{6}$ See: www.jpost.com/National-News/Farewell-to-the-agora-and-the-phenomenon-of-prices-that-cant-be-paid-336741 (accessed March 1, 2017). The asymmetry was caused by the rounding rule that was adopted by the Bank of Israel for the non 0 -ending prices. If a total bill ended with 1, 2, 3, or 4 agorot, the price was rounded down, and if it ended with 5, 6, 7, 8, or 9 agorot, then it was rounded up. Thus, in four cases, the price was rounded down and in five cases, it was rounded up. In a survey conducted by the Israel Consumer Council as part of its project of constructing a fairness index for the retail industry, Israeli consumers ranked 9-ending prices as the most unfair practice of the food retailers, well above price mistakes, misleading promotional campaigns, lack of transparency, etc. Source: www.consumers.org.il/item/fairness index (in Hebrew), and www.consumers.org.il/?catid=\%7B36654ED8-AA18-4882-A471-BCB94C7F103B\%7D (both accessed February 18, 2017).
} 
price endings at three points in time: before the regulation was announced, immediately after it went into effect, and 7-months after it went into effect. Panel (a) shows the distribution of price endings in July 2013-August 2013, two months before the regulation was announced, and half a year before non 0 -ending prices were abolished. At that time, about $60 \%$ of the prices ended in 99 and 5\% in 49 . In total, in that period $72 \%$ of the prices were 9 -ending. The share of 90 -ending prices was only about $2.3 \%$.

Panel (b) depicts the price endings' distribution in January 2014-February 2014, immediately after the regulation went into effect. As can be seen, the share of 00-ending prices increased from $4 \%$ before the regulation, to over $23 \%$ after the regulation. The share of 90 ending prices increased from $2.3 \%$ to over $47 \%$. Thus, it seems that following the abolition of non 0-ending prices, many 99-ending prices were converted to 90-ending prices or were rounded up to 00-ending prices. Panel (c) shows that by July 2014-August 2014, the share of 90-ending prices has reached about 55\%, while the share of 00-ending prices went down to $18 \%$.

The figures reported by Aalto-Setala (2005) suggest that the Finish experience was similar but in the reverse direction. Before the Euro changeover, the price level in Finland was similar to the price level in Israel. Also, there were no 1- and 5-penniä coins in Finland, like in Israel. At that time about $72 \%$ of the prices were 90 -ending, and only $0.1 \%$ of the prices were 9 ending, like it was in Israel after the regulatory change. Similarly, after the Euro changeover, the share of 9-ending prices has increased to about 34\%, while the share of 90-ending prices has decreased from $72 \%$ to below 21\%. In terms of the speed of adjustment, Finish retailers needed two years until 9-endings emerged as their favorite price point. In Israel, in contrast, it took less than 7-months, until 90-endings became the Israeli retailers’ favorite price point. ${ }^{7}$

\section{Survey Data: “before,” “immediately-after,” and “one-year after”}

We conducted three surveys: (1) in October 2013-December 2013, (2) in January 2014March 2014, and (3) in January 2015-March 2015. ${ }^{8}$ Shoppers exiting stores were shown a list of goods, and were asked to mark the goods they had purchased and indicate their prices. In

\footnotetext{
${ }^{7}$ Although the conditions in both countries were similar, in Israel it was a regulatory change that made 90-endings the retailers' preferred ending, whereas in Finland, it seems, the retailers voluntarily adopted 90 as their preferred price ending. We speculate that prior to the Euro changeover, 9-endings were not that valuable because of the lower value of the Finnish currency relative to the Euro. The conversion to the Euro, then, could have made the finer level of currency divisibility more valuable, making 9-ending prices more popular among Finish retailers. The Israeli retailers, however, were able to use 9endings, to take advantage of the finer level of divisibility in their pricing, until the regulation banned it. A possible reason for the difference between Finland and Israel might be the difference in their average per capita income. It could be that in Finland, because of their higher per capita income, the relative value of penniä was not high enough for the retail sector to use it in transactions.

${ }^{8}$ These survey dates do not coincide exactly with the three sub-periods covered by the dataset presented in Figure 1 . The latter dataset, which pertains to July-August 2013, January-February 2014, and July-August 2014, was obtained from the Israel's Central Bureau of Statistics only lately, after we have completed the surveys. Because of our survey method, we do not control the survey shoppers' identity, and therefore the shoppers included in the three survey samples are different.
} 
the third survey, in addition to the above questions, they were also asked to indicate whether in their opinion the prices have increased, decreased or remained unchanged, relative to the previous week.

The list included regularly consumed goods in 20 categories. ${ }^{9}$ Table 1 gives summary statistics for three periods: (a) before the regulation went into effect, (b) immediately after it went into effect, and (c) one year after it was in effect. Along with some socio-demographic data, Table 1 presents the shares of 9- and 90-ending prices shoppers reported, and the average absolute percentage error they made in recalling prices. The error started at $9 \%$ in October 2013-December 2013, declined to 5.7\% immediately after the regulation went into effect, and rose back, reaching $10 \%$ in survey 3, one year later. The share of 9-ending prices in 2013 is only $18.6 \%$, as retailers cut the use of 9-endings in preparation of the regulatory requirement. From January 1, 2014 and thereafter, the share of 9-ending prices is zero, as required by the regulation. Consistent with Figure 1, the share of 90-ending prices was only $12.5 \%$ before the regulation went into effect, rose to $24 \%$ immediately after it went into effect, and continued rising, reaching $50 \%$ in survey 3 , one year later.

\section{Econometric model and estimation results}

\subsection{Before the regulation went into effect: October 2013-December 2013}

We use the data from survey 1 to assess the effect of 9-endings on shoppers' price recall. Thomas and Morwitz (2005) show that shoppers process price information L-to-R and often they are inattentive to the rightmost digits. Consistent with the image-effect, Levy et al. (2016) find that when shoppers use price endings as a signal for low prices, they are inattentive to the price itself. We thus expect that shoppers will be less precise in recalling 9ending prices in comparison to other prices.

To assess the effect of 9-endings on shoppers’ price recall, we first focus on survey 1 data, covering the period October 2013-December 2013, i.e., when non 0-ending prices were still allowed. We estimate a random effect regression, and report robust standard errors, which are clustered at the participants' level. The dependent variable is the percentage absolute error. See columns (1)-(4) of Table 2. Column (1) reports the results when the only RHS variable is a 9-ending dummy (1 for 9-ending price, 0 otherwise). In columns (2)-(4) we add controls. When interpreting the results, note that the dependent variable is the percentage absolute error, and therefore negative coefficients indicate better price recall.

For 9-ending prices, shoppers' price recall error is $2 \%$ higher than for other prices. The

\footnotetext{
${ }^{9}$ The products include: cottage cheese, soft cheese, semi-hard cheese, fresh milk, chocolate drink, Coca-Cola, Diet Coke, mineral water, tomatoes, cucumbers, oranges, lemons, chocolate spread, dark chocolate, peanut flavor snack, pastrami, eggs, white sugar, margarine and sunflower oil.
} 
addition of control variables (column 2) does not affect the coefficient of 9-endings. ${ }^{10}$

The 9-ending effect could be due to level-effect or due to image-effect. If it is the former, then consumers should have made larger errors also when prices ended with other non-zero endings in comparison to round endings. To test this hypothesis, we include a control for prices that end in cents other than 9 (column 3). The coefficient of 9-endings is unaffected by the inclusion of the cent-dummy. The cent-dummy is statistically insignificant. These results are consistent with the hypothesis that 9-endings influence the shoppers' price perceptions through the image-effect.

We also test for the effect of 90-endings because later we test whether 90-endings have a negative effect on shoppers' price recall after the elimination of 9-endings. It could be that such an effect was present even before 9-endings were eliminated. We therefore add to the regression both a 90 -ending dummy ( 1 for 90 -ending price, 0 otherwise) and a 0 -ending dummy ( 1 for 0 -ending price but not 90 -ending, 0 otherwise). See column (4).

The coefficient of 0 -ending is negative and significant, consistent with the argument that 0-ending numbers are cognitively more accessible (Dehaene 1997), and thus they are recalled better than non 0-ending prices (Schindler and Kirby 1997). The coefficient of 90-endings is also negative, and its absolute value exceeds the absolute value of the coefficient of other 0endings $\left(\chi^{2}=2.77, p<0.1\right)$. Thus, before 9-endings were abolished, 90-endings, if anything, had a positive effect on price recall accuracy when compared to other 0-ending prices.

\subsection{Immediately after the regulation went into effect: January 2014-March 2014}

In columns 5-6 of Table 2, we use the data collected in survey 1 (October 2013December 2013) and survey 2 (January 2014-March 2014), to test whether the shoppers’ price recall has changed after the regulation banning non 0 -ending prices. In column 5 , the only independent variable is a dummy for the period after the regulation ( 1 if it is after January 1, 2014, 0 otherwise). We find that after January 2014, the average error the shoppers made decreased by 3\%. In column (6), we add the same controls as in column (2). The coefficient estimate of the after-january-2014 dummy is unchanged.

In column (7) we test whether 90 endings had an effect on consumers' price recall immediately after the regulatory change, given that by January 2014 the share of 90-ending prices has already increased to almost 50\%. We therefore add to the regression a dummy for

\footnotetext{
${ }^{10}$ The control variables include: the age, goods' prices, household size, number of cars owned, number of supermarkets the shoppers frequent, the average amount spent per shopping trip, and dummies for gender ( 1 if woman, 0 if man), marital status (1 if married, 0 otherwise), academic degree (1 if an academic degree, 0 otherwise), ultra-religious ( 1 if the shopper identifies himself as ultra-religious, 0 otherwise) and frequent buyer ( 1 if shops more than once a week, 0 otherwise). We control for ultra-religious households because they tend to have low incomes and large families. We also include dummies for the shop and for product categories. To save space, the coefficients of the latter are not reported.
} 
90-endings and use only the data from survey 2, covering the period immediately after the regulatory change, January 2014-March 2014. The coefficient of the 90-endings dummy is negative but statistically insignificant, suggesting that shoppers made similar, or even smaller errors, when recalling 90-ending prices in comparison to other prices.

\subsection{A year after the regulation went into effect: January 2015-March 2015}

Next, we use the data collected in survey 3 to study what happened one year after the regulatory change. See Table 3. We estimate random effects regressions, and report robust standard errors, which are clustered at the shoppers' level. The dependent variable is the percentage absolute error. In column 1, the only independent variable is a 90-ending dummy (1 for 90-ending price, 0 otherwise). We find that the effect of 90-endings is positive and significant. Thus, one year after 9-endings were eliminated, shoppers made larger errors in recalling 90-ending prices in comparison to other prices.

For robustness, we add the controls listed in footnote 10. See column (2). The coefficient of 90 -endings remains significant, although its value drops from $4 \%$ to $3 \%$. This point estimate is still larger than the one we find for 9-endings before the regulatory change, $2 \%$. Thus, our results suggest that the effect of 90-endings after the regulation was introduced, is at least as large as the effect that 9-endings had before the regulatory change.

As an additional robustness check, we use data on sales. For 5 of the 7 shops sampled, we have data on the goods that were on sale. We use these data to add a dummy variable for sales (1 if the good was on sale, 0 otherwise). See column (3). The coefficient of the sales dummy is negative and significant, suggesting that shoppers made smaller errors in recalling the prices of goods on sale. We find, however, that the effect of 90-endings is larger with control for sales than without.

To assess whether the effect of 90-endings on price recall is because of the level-effect or the image-effect, we use data on shoppers' recall of price changes. If they make larger errors in recalling 90-ending prices because they pay attention to leftmost digits only, then 90endings should have little effect on the shoppers' recall of price changes. If they use 90endings as a signal for low prices, however, then 90-endings should reduce the likelihood of noticing price changes.

Levy et al. (2016) show that before 9-endings were abolished, shoppers in Israel were indeed less likely to notice a price change when the new price was 9-ending than when the new price ended in a different digit. We test whether 90-endings have a similar effect after 9endings were eliminated by estimating a random effect probit regression of the probability that shoppers correctly recall changes of 9-ending prices. 
We use data from the 5 shops where shoppers were asked to indicate whether goods' prices had increased, decreased or remained unchanged. The dependent variable is a dummy variable that equals 1 if the shopper responded correctly, and 0 otherwise. The shoppers recalled price changes correctly in 53\% of the cases. See column (1) in Table 4.

We find that shoppers are less likely to notice a price change if the price ends with 90 . If a price is not 90 -ending, the probability of noticing a price change is $63 \%$. If a price is 90 ending, then the probability of noticing a price change is $41 \%$.

We run three robustness checks. First, we add the controls listed in footnote 10 (column 2). The effect of 90-endings is still negative and significant, although its value slightly decreases. Second, we add a control for sales (column 3). The coefficient of 90-endings remains significant. Third, we add the absolute percentage price change (column 4). The size and the significance of the coefficient of 90-ending remain the same.

\section{Conclusion}

Until January 2014, Israeli retailers were free to use 9-ending prices. Since January 1, 2014, the use of 9-endings has been prohibited, bringing an end to 9-ending prices, and limiting the retailers' price-setting flexibility. We find that prior to this regulatory change, 9endings had a negative effect on shoppers' price recall. Further, we find that immediately after the regulatory change, shoppers’ price recall has improved.

The new regulation has accomplished one of its goals, i.e., the elimination of the asymmetric rounding of cash transaction bills, which favored the retailers. The outlawing of 9-ending prices, however, failed to accomplish its second goal, which was to stop the manipulative pricing which the public attributed to the frequent use of 9-endings by the retailers. One year after the regulatory change, 90-endings have "turned into" the new 9endings, in the sense that they seem to have similar manipulative effects on the shoppers. We find that 90-endings have acquired the status of 9-endings through the image-effect, suggesting that 90-ending prices are popular in the new setting because 90-endings are used by shoppers as a signal for low prices. That is, 90-ending prices are the new psychological price points.

These findings confirm once again that the market reacts to regulatory changes. The Israeli retailers had a preferred price ending, 9, but it was made illegal by regulators. The retailers' response was to find a new price ending, 90, which plays the same role. The shoppers benefited from the use of 9-endings as a signal for low prices until the regulatory change. After the change, all prices end with 0 , eliminating the value of 0 -endings as a signal. The retail prices have converged to 90-endings, to which shoppers responded by ignoring the 
0-endings and treating the 90-ending prices as 9-ending. The end result is that the retailers' and the shoppers' reaction to the regulatory intervention has partially eliminated the regulation’s intended effect. 


\section{References}

Aalto-Setala, V., 2005. How do markets behave? The adjustment of price endings. Journal of Product \& Brand Management 14 (7), 455-459.

Anderson, E., Jaimovich, N., Simester, D., 2015. Price stickiness: empirical evidence of the menu cost channel. Review of Economics and Statistics 97 (4), 813-826.

Anderson, E.T., Simester, D.I., 2003. Effects of $\$ 9$ price endings on retail sales: evidence from field experiments. Quantative Marketing and Economics 1, 93-110.

Ater, I., Gerlitz, O., 2016. Round prices and price rigidity: evidence from outlawing odd prices. Discussion Paper No. 16.05, the Maurice Falk Institute for Economic Research in Israel. Link: http://www.falk.huji.ac.il/sites/default/files/falkheb/files/paper_16-05.pdf

Blinder, A.S., 1991. Why are prices sticky? Preliminary results from an interview study. American Economic Review 81 (2), 89-96.

Blinder, A.S., Canetti, E.D., Lebow, D.E., Rudd, J.B., 1998, Asking about prices: A new approach to understanding price stickiness (Russell Sage Foundation, New York).

Dehaene, S., 1997, The number sense: How the mind creates mathematics (Oxford University Press, New York).

Ehrmann, M., 2010. Inflation developments and perceptions after the Euro cash changeover. German Economic Review 12 (1), 33-58.

Kashyap, A.K., 1995. Sticky prices: new evidence from retail catalogues. Quarterly Journal of Economics 110, 245-274.

Knotek, E., 2010. The roles of menu costs and nine endings in price rigidity. Working Paper No. 10-18, Federal Reserve Bank of Kansas City. Available at: www.kansascityfed.org/publicat/reswkpap/pdf/rwp10-18.pdf.

Landsburg, S.E., 2012, The armchair economist (Simon and Schuster, London).

Levy, D., Lee, D., Chen, H., Kauffman, R., Bergen, M., 2011. Price points and price rigidity. Review of Economics and Statistics 93 (4), 1417-1431.

Levy, D., Snir, A., Gotler, A., Chen, H., 2016. Not all price endings are created equal: price points and asymmetric price rigidity. Unpublished manuscript.

McShane, B., Chen, C., Anderson, E., Simester, D., 2015. Decision stages and asymmetries in regular retail price pass-through. Marketing Science 35 (4), 619-629.

Schindler, R.M., Kirby, P., 1997. Patterns of right most digits used in advertised prices. Journal of Consumer Research 24, 192-200.

Stiving, M., 2000. Price-endings when prices signal quality. Management Science 46 (12), 1617-1629.

Stiving, M., Winer, R., 1997. An empirical analysis of price-endings with scanner data. Journal of Consumer Research 24 (1), 57-67.

Thomas, M., Morwitz, V., 2005. Penny wise and pound foolish: the left-digit effect in price cognition. Journal of Consumer Research 32, 54-64. 
(a) July 2013-Aug. 2013 (Before the regulation went into effect)

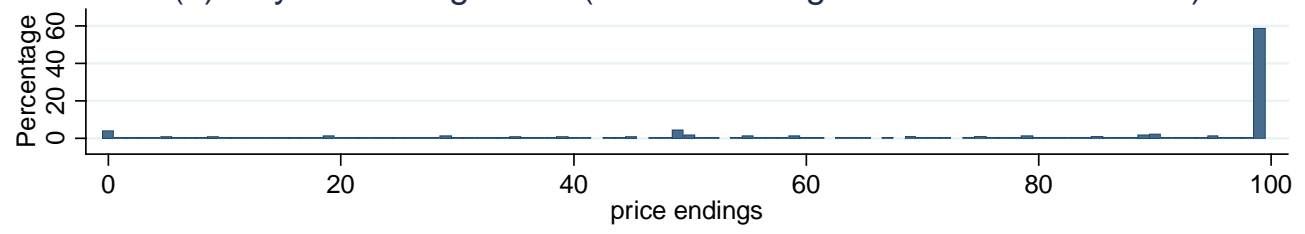

(b) Jan. 2014-Feb. 2014 (Immediately after the regulation went into effect)

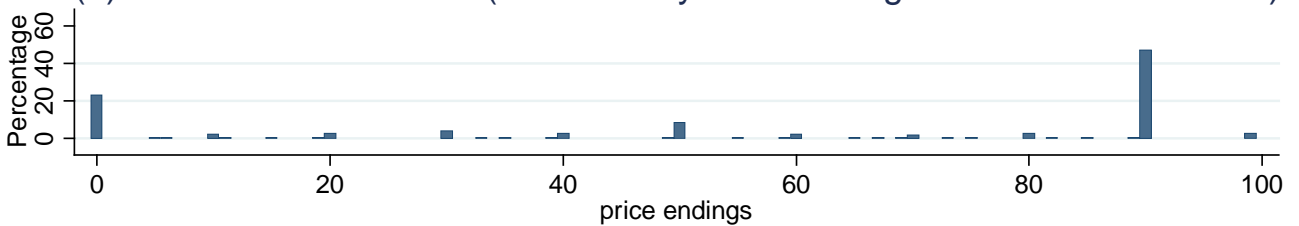

(c) July 2014-Aug. 2014 (7-Months after the regulation went into effect)

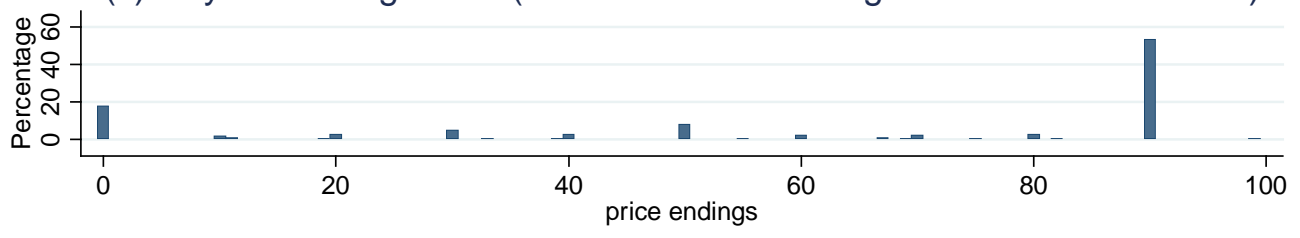

Fig. 1. The distributions of price-endings: (a) July-August $2013(n=3,211)$, (b) January-February $2014(n=3,178)$, and (c) July-August 2014 ( $n=$ 1,548)

Notes:

1. The figure uses monthly price data that are collected regularly by the Israel's Central Bureau of Statistics for compiling the CPI.

2. The data include the prices of goods in 103 product categories, collected at supermarkets and drugstores in Israel. 


\section{Table 1}

Summary statistics: survey 1 (before the regulatory change), survey 2 (immediately after the regulatory change) and survey 3 (One-year after the regulatory change)

\begin{tabular}{|c|c|c|c|}
\hline & $\begin{array}{c}\text { (a) } \\
\text { Survey } \mathbf{1} \\
\text { Oct. 2013-Dec. } 2013 \\
\text { "Before" }\end{array}$ & $\begin{array}{c}\text { (b) } \\
\text { Survey } 2 \\
\text { Jan. 2014-March 2014 } \\
\text { "Immediately after” }\end{array}$ & \begin{tabular}{|c|} 
(c) \\
Survey 3 \\
Jan. 2015-March 2015 \\
"One-year after”
\end{tabular} \\
\hline Age & $\begin{array}{c}39.16 \\
(17.034)\end{array}$ & $\begin{array}{c}37.036 \\
(15.058)\end{array}$ & $\begin{array}{c}44.26 \\
(14.112)\end{array}$ \\
\hline Household size & $\begin{array}{c}2.73 \\
(1.638)\end{array}$ & $\begin{array}{c}2.88 \\
(1.668)\end{array}$ & $\begin{array}{c}3.79 \\
(1.707)\end{array}$ \\
\hline \% of Women & $52 \%$ & $49 \%$ & $56 \%$ \\
\hline$\%$ of Academic & $40 \%$ & $37 \%$ & $39 \%$ \\
\hline$\%$ of Married & $58 \%$ & $54 \%$ & $71 \%$ \\
\hline \% of Ultra-religious & $2 \%$ & $3 \%$ & $4 \%$ \\
\hline No. of cars owned & $\begin{array}{c}1.20 \\
(0.827)\end{array}$ & $\begin{array}{c}1.21 \\
(0.763)\end{array}$ & $\begin{array}{c}1.41 \\
(0.793)\end{array}$ \\
\hline No. of shops visited & $\begin{array}{c}1.53 \\
(0.873)\end{array}$ & $\begin{array}{c}1.43 \\
(0.765)\end{array}$ & $\begin{array}{c}1.92 \\
(1.020)\end{array}$ \\
\hline $\begin{array}{l}\text { Average amount spent } \\
\text { per shopping trip }\end{array}$ & $\begin{array}{c}340.59 \\
(223.404) \\
\end{array}$ & $\begin{array}{c}384.97 \\
(216.605) \\
\end{array}$ & $\begin{array}{c}446.48 \\
(222.681) \\
\end{array}$ \\
\hline $\begin{array}{l}\% \text { of shopping more } \\
\text { than once a week }\end{array}$ & $37 \%$ & $42 \%$ & $12 \%$ \\
\hline Average recall error & $8.94 \%$ & $5.69 \%$ & $10.05 \%$ \\
\hline$\%$ of 9-ending prices & $18.64 \%$ & $0.01 \%$ & $\mathrm{~N} / \mathrm{A}$ \\
\hline$\%$ of 90-ending prices & $12.47 \%$ & $24.05 \%$ & $47 \%$ \\
\hline $\begin{array}{l}\text { Responses (no. of } \\
\text { products purchased per } \\
\text { shopper) }\end{array}$ & 6.41 & 5.77 & 5.22 \\
\hline No. of shops & 13 & 13 & 7 \\
\hline No. of shoppers & 364 & 740 & 513 \\
\hline
\end{tabular}


Table 2

Regression of the price recall error before and immediately after the regulatory change

\begin{tabular}{|c|c|c|c|c|c|c|c|}
\hline & \multicolumn{4}{|c|}{$\begin{array}{l}\text { Before the regulatory } \\
\text { change } \\
\text { (October 2013-December 2013) }\end{array}$} & \multicolumn{3}{|c|}{$\begin{array}{c}\text { Immediately after the regulatory } \\
\text { change } \\
\text { (January 2014-March 2014) }\end{array}$} \\
\hline Variable & $(1)$ & $(2)$ & (3) & $(4)$ & $(5)$ & $(6)$ & $(7)$ \\
\hline 9-ending & $\begin{array}{l}0.02 * * * \\
(0.007) \\
\end{array}$ & $\begin{array}{c}0.02^{* * *} \\
(0.005)\end{array}$ & $\begin{array}{l}0.02 * * \\
(0.005)\end{array}$ & & & $\begin{array}{c}0.01 \\
(0.006)\end{array}$ & \\
\hline Good's price & & $\begin{array}{c}-0.001 * * * \\
(0.0003)\end{array}$ & $\begin{array}{c}-0.001 * * * \\
(0.0003) \\
\end{array}$ & $\begin{array}{c}-0.001 * * * \\
(0.0003)\end{array}$ & & $\begin{array}{c}-0.002 * * * \\
(0.0004)\end{array}$ & $\begin{array}{c}-0.002^{* * *} \\
(0.0004)\end{array}$ \\
\hline Age & & $\begin{array}{c}0.0001 \\
(0.0003)\end{array}$ & $\begin{array}{c}0.0001 \\
(0.0003) \\
\end{array}$ & $\begin{array}{c}0.0001 \\
(0.0003)\end{array}$ & & $\begin{array}{l}-0.0002 \\
(0.0001)\end{array}$ & $\begin{array}{l}-0.0002 \\
(0.0001)\end{array}$ \\
\hline $\begin{array}{l}\text { Household } \\
\text { size }\end{array}$ & & $\begin{array}{c}0.004 \\
(0.003)\end{array}$ & $\begin{array}{c}0.004 \\
(0.003) \\
\end{array}$ & $\begin{array}{c}0.004 \\
(0.003) \\
\end{array}$ & & $\begin{array}{c}0.002 \\
(0.002)\end{array}$ & $\begin{array}{c}-0.0004 \\
(0.002) \\
\end{array}$ \\
\hline No. of cars & & $\begin{array}{l}-0.005 \\
(0.004) \\
\end{array}$ & $\begin{array}{l}-0.005 \\
(0.004) \\
\end{array}$ & $\begin{array}{l}-0.004 \\
(0.004) \\
\end{array}$ & & $\begin{array}{c}-0.0001 \\
(0.003) \\
\end{array}$ & $\begin{array}{l}0.006^{*} \\
(0.003) \\
\end{array}$ \\
\hline $\begin{array}{l}\text { No. of } \\
\text { supermarkets } \\
\text { visited }\end{array}$ & & $\begin{array}{l}-0.002 \\
(0.005)\end{array}$ & $\begin{array}{l}-0.002 \\
(0.005)\end{array}$ & $\begin{array}{c}-0.002 \\
(0.0005)\end{array}$ & & $\begin{array}{c}-0.0008 \\
(0.003)\end{array}$ & $\begin{array}{l}-0.002 \\
(0.003)\end{array}$ \\
\hline $\begin{array}{l}\text { Average } \\
\text { amount spent }\end{array}$ & & $\begin{array}{c}0.00003 \\
(0.00002)\end{array}$ & $\begin{array}{c}0.00003 \\
(0.00002)\end{array}$ & $\begin{array}{c}0.00003 \\
(0.00002)\end{array}$ & & $\begin{array}{c}-0.00006 \\
(0.002)\end{array}$ & $\begin{array}{l}-0.002 \\
(0.002)\end{array}$ \\
\hline Woman & & $\begin{array}{c}0.01 \\
(0.010)\end{array}$ & $\begin{array}{c}0.01 \\
(0.010)\end{array}$ & $\begin{array}{c}0.01 \\
(0.010)\end{array}$ & & $\begin{array}{c}0.006 \\
(0.004)\end{array}$ & $\begin{array}{c}0.005 \\
(0.004)\end{array}$ \\
\hline Married & & $\begin{array}{l}-0.02^{*} \\
(0.010)\end{array}$ & $\begin{array}{l}-0.02^{*} \\
(0.010)\end{array}$ & $\begin{array}{l}-0.02^{*} \\
(0.010)\end{array}$ & & $\begin{array}{c}-0.01^{* *} \\
(0.004)\end{array}$ & $\begin{array}{l}-0.006 \\
(0.004)\end{array}$ \\
\hline $\begin{array}{l}\text { Academic } \\
\text { degree }\end{array}$ & & $\begin{array}{c}0.001 \\
(0.008)\end{array}$ & $\begin{array}{c}0.001 \\
(0.007)\end{array}$ & $\begin{array}{c}0.001 \\
(0.007)\end{array}$ & & $\begin{array}{l}-0.004 \\
(0.003)\end{array}$ & $\begin{array}{l}-0.003 \\
(0.003)\end{array}$ \\
\hline $\begin{array}{l}\text { Ultra- } \\
\text { religious }\end{array}$ & & $\begin{array}{c}-0.02 * * \\
(0.011)\end{array}$ & $\begin{array}{c}-0.03^{* *} \\
(0.012)\end{array}$ & $\begin{array}{c}-0.03^{* *} \\
(0.012)\end{array}$ & & $\begin{array}{c}-0.01 \\
(0.011)\end{array}$ & $\begin{array}{c}-0.0004 \\
(0.013)\end{array}$ \\
\hline $\begin{array}{l}\text { Frequent- } \\
\text { shopper }\end{array}$ & & $\begin{array}{l}-0.005 \\
(0.008)\end{array}$ & $\begin{array}{l}-0.005 \\
(0.008)\end{array}$ & $\begin{array}{l}-0.005 \\
(0.008)\end{array}$ & & $\begin{array}{c}0.001 \\
(0.003)\end{array}$ & $\begin{array}{c}0.006 \\
(0.004)\end{array}$ \\
\hline Cent ending & & & $\begin{array}{c}0.01 \\
(0.007)\end{array}$ & & & & \\
\hline 90-ending & & & & $\begin{array}{c}-0.02 * * * \\
(0.005)\end{array}$ & & & $\begin{array}{l}-0.002 \\
(0.004)\end{array}$ \\
\hline 0-ending & & & & $\begin{array}{l}-0.01 * \\
(0.006)\end{array}$ & & & \\
\hline $\begin{array}{l}\text { After January } \\
2014\end{array}$ & & & & & $\begin{array}{c}-0.03 * * * \\
(0.005)\end{array}$ & $\begin{array}{c}-0.03^{* * *} \\
(0.004)\end{array}$ & \\
\hline Constant & $\begin{array}{l}0.08 * * * \\
(0.004) \\
\end{array}$ & $\begin{array}{l}0.06^{* * * *} \\
(0.020)\end{array}$ & $\begin{array}{c}0.005^{* *} \\
(0.021) \\
\end{array}$ & $\begin{array}{l}0.06^{* * * *} \\
(0.020)\end{array}$ & $\begin{array}{c}0.09 * * * \\
(0.004)\end{array}$ & $\begin{array}{l}0.09 * * * \\
(0.009)\end{array}$ & $\begin{array}{l}0.08 * * * \\
(0.009)\end{array}$ \\
\hline$n$ & 2,333 & 2,333 & 2,333 & 2,333 & 6,892 & 6,892 & 4,378 \\
\hline$\chi^{2}$ & 15.97 & 1645.06 & 1930.80 & 2580.87 & 38.7 & 3848.7 & $16,910.3$ \\
\hline
\end{tabular}

Notes:

1. The table reports the results of a random effects regression. The dependent variable is the percentage absolute error in price recall.

2. The standard errors are robust, and they are clustered at the participants' level.

3 . $* * *, * *$, and $*$ indicate significance at $1 \%, 5 \%$, and $10 \%$, respectively. 
Table 3

Regression of the price recall error one year after the regulatory change, January 2015-March 2015

\begin{tabular}{|c|c|c|c|}
\hline Variable & $(1)$ & $(2)$ & (3) \\
\hline 90-ending & $\begin{array}{l}0.04^{* * *} \\
(0.010)\end{array}$ & $\begin{array}{l}0.03^{* *} \\
(0.02)\end{array}$ & $\begin{array}{l}0.06 * * * \\
(0.023)\end{array}$ \\
\hline Good's price & & $\begin{array}{c}0.0008 \\
(0.0008)\end{array}$ & $\begin{array}{l}0.0009 \\
(0.001) \\
\end{array}$ \\
\hline Age & & $\begin{array}{l}-0.0003 \\
(0.0003) \\
\end{array}$ & $\begin{array}{l}-0.0006 \\
(0.0005)\end{array}$ \\
\hline Household size & & $\begin{array}{c}0.006 \\
(0.004)\end{array}$ & $\begin{array}{c}0.006 \\
(0.005)\end{array}$ \\
\hline No. of cars & & $\begin{array}{l}0.02 * * \\
(0.008)\end{array}$ & $\begin{array}{l}0.02 * * \\
(0.009)\end{array}$ \\
\hline $\begin{array}{l}\text { No. of supermarkets } \\
\text { visited }\end{array}$ & & $\begin{array}{l}0.0006 \\
(0.007) \\
\end{array}$ & $\begin{array}{c}-0.00007 \\
(0.008) \\
\end{array}$ \\
\hline Average amount spent & & $\begin{array}{c}-0.00007^{*} \\
(0.00004)\end{array}$ & $\begin{array}{r}-0.00007^{*} \\
(0.00004)\end{array}$ \\
\hline Woman & & $\begin{array}{c}0.004 \\
(0.004) \\
\end{array}$ & $\begin{array}{l}0.004 \\
(0.01) \\
\end{array}$ \\
\hline Married & & $\begin{array}{l}-0.0009 \\
(0.010) \\
\end{array}$ & $\begin{array}{l}-0.007 \\
(0.014) \\
\end{array}$ \\
\hline Academic degree & & $\begin{array}{l}-0.002) \\
(0.009) \\
\end{array}$ & $\begin{array}{c}-0.01 \\
(0.013)\end{array}$ \\
\hline Ultra-religious & & $\begin{array}{c}0.009 \\
(0.027) \\
\end{array}$ & $\begin{array}{c}0.02 \\
(0.03) \\
\end{array}$ \\
\hline Frequent shopper & & $\begin{array}{c}-0.02 \\
(0.014)\end{array}$ & $\begin{array}{l}-0.01) \\
(0.02)\end{array}$ \\
\hline Sales & & & $\begin{array}{c}-0.03 \\
(0.012)\end{array}$ \\
\hline Constant & $\begin{array}{l}0.08 * * * \\
(0.008)\end{array}$ & $\begin{array}{c}-0.08 * * \\
(0.035)\end{array}$ & $\begin{array}{l}-0.07^{*} \\
(0.044)\end{array}$ \\
\hline$n$ & 2,587 & 2,587 & 1,855 \\
\hline$\chi^{2}$ & 15.67 & 293.90 & 215.68 \\
\hline
\end{tabular}

Notes:

1. In the table, we report the results of a random effects regression. The dependent variable is a \% absolute error in price recall.

2. We report robust standard errors, which are clustered at the participants' level.

3. ***, **, and * indicate significance at $1 \%, 5 \%$, and $10 \%$, respectively 
Table 4

Regression of the probability that shoppers notice a price change one year after the regulatory change, January 2015-March 2015

\begin{tabular}{|l|c|c|c|c|}
\hline Variable & $(1)$ & $(2)$ & $(3)$ & $(4)$ \\
\hline 90-ending & $-0.56^{* * *}$ & $-0.25^{* * *}$ & $-0.32^{* * *}$ & $-0.37^{* * *}$ \\
& $(0.068)$ & $(0.077)$ & $(0.107)$ & $(0.106)$ \\
\hline Good's price & & $-0.01^{* *}$ & -0.01 & -0.01 \\
& & $(0.006)$ & $(0.007)$ & $(0.007)$ \\
\hline Age & & -0.005 & -0.005 & -0.002 \\
& & $(0.003)$ & $(0.004)$ & $(0.004)$ \\
\hline Household size & & 0.03 & 0.04 & 0.05 \\
& & $(0.029)$ & $(0.036)$ & $(0.031)$ \\
\hline No. of cars & & 0.08 & -0.12 & -0.08 \\
& & $(0.062)$ & $(0.078)$ & $(0.068)$ \\
\hline No. of supermarkets & & $-0.11^{* *}$ & $-0.15^{* *}$ & $-0.11^{*}$ \\
visited & & $(0.055)$ & $(0.068)$ & $(0.067)$ \\
\hline Average amount spent & & 0.0002 & 0.0003 & 0.0002 \\
& & $(0.0002)$ & $(0.0003)$ & $(0.00003)$ \\
\hline Woman & & -0.09 & -0.14 & -0.11 \\
& & $(0.079)$ & $(0.101)$ & $(0.088)$ \\
\hline Married & & -0.11 & $-0.29^{* *}$ & $-0.28^{* *}$ \\
& & $(0.094)$ & $(0.125)$ & $(0.108)$ \\
\hline Academic degree & & -0.01 & -0.002 & 0.08 \\
& & $(0.085)$ & $(0.111)$ & $(0.095)$ \\
\hline Ultra-religious & & -0.28 & -0.29 & -0.29 \\
& & $(0.196)$ & $(0.22)$ & $(0.195)$ \\
\hline Frequent shopper & & 0.02 & 0.04 & -0.06 \\
& & $(0.0129)$ & $(0.177)$ & $(0.151)$ \\
\hline Sales & & & $-1.16^{* * *}$ & $-1.10^{* * *}$ \\
& & & $(0.171)$ & $(0.173)$ \\
\hline Size of price change & & $0.91^{* * *}$ & $1.00^{* * *}$ & $1.04^{* * *}$ \\
& & $(0.253)$ & $(0.328)$ & $(0.286)$ \\
\hline Constant & & 3,191 & 1,441 & 1,373 \\
\hline$n$ & & & 272.34 & 227.58 \\
\hline
\end{tabular}

Notes:

1. In the table, we report the results of a random effects probit regression. The dependent variable is a dummy variable that equals 1 if the consumer responded correctly (and 0 otherwise) whether the price has increased, decreased, or remained unchanged.

2. We report robust standard errors, which are clustered at the participants' level.

3. ***, $* *$, and $*$ indicate significance at $1 \%, 5 \%$, and $10 \%$, respectively 